\section{New synonymy in Euconnus Thomson, 1859 (Coleoptera, Scydmaenidae)}

M. A. Alonso-Zarazaga

Depto. de Biodiversidad y Biología Evolutiva Museo Nacional de Ciencias Naturales (CSIC)

C/. José Gutiérrez Abascal, 2

E-28006 Madrid

Alonso-Zarazaga (2004) proposed the replacement name Euconnus (Tetramelus) arabiae nom. nov. for the homonym nominal species Euconnus (Tetramelus) apfelbecki Franz, 1968 (non Csiki, 1919). His paper bears the publication date $25^{\text {th }}$ August 2004.

In the same year, Davies (2004) proposed another replacement name for the same homonym species, namely, Euconnus (Tetramelus) cetinjensis Davies nom. nov. His work bears the date $31^{\text {st }}$ December 2004.

It is clear that both nominal species are objective synonyms, because they are replacement names for the same homonymic name, and that, according to the Principle of Priority, the oldest name is the valid one. Consequently, the following synonymy is established: Euconnus (Tetramelus) arabiae AlonsoZarazaga, $2004=$ Euconnus (Tetramelus) cetinjensis Davies, 2004, syn. nov.

\section{References}

Alonso-Zarazaga, M. A., 2004. Nombre de reemplazo en Euconnus Thomson, 1859 (Coleoptera, Scydmaenidae). Graellsia, 60(1): 127.

DAVIES, A., 2004. Tribe Cyrtoscydmini L.W. Schaufuss, 1889. In: I. Loebl \& A. Smetana (eds.). Catalogue of Palaearctic Coleoptera. Volume 2: Hydrophiloidea Histeroidea - Staphylinoidea. Apollo Books. Stenstrup: 206-224.

Recibido, 4-V-2007 Aceptado, 10-V-2007 Publicado, 27-VI-2007 